\title{
EFFECTIVENESS OF DUNG BEETLES AS BIOINDICATORS OF ENVIRONMENTAL CHANGES IN LAND-USE GRADIENT IN SULAWESI, INDONESIA
}

\author{
SHAHABUDDIN $^{1 *}$, USWAH HASANAH ${ }^{1}$, and ELIJONNAHDI ${ }^{2}$ \\ ${ }^{1}$ Department of Agrotechnology Faculty of Agriculture University of Tadulako, \\ Palu 94118, Central Sulawesi, Indonesia \\ ${ }^{2}$ Department of Biology Faculty of Mathematics and Science University of Tadulako, \\ Palu 94118, Central Sulawesi, Indonesia
}

Received 13 June 2013/Accepted 09 November 2013

\begin{abstract}
Bioindicators have been widely accepted as useful tools for monitoring and detecting changes in the environment or habitat condition. By using bioindicators, it is possible to assess the impact of human activities on the biota, instead of examining the entire biota. In this paper we analyzed diversity of dung beetles (Coleoptera: Scarabaeidae) across land use gradient in Central Sulawesi and tested the suitability of dung beetles as bioindicators for environmental changes. Ninety baited pitfall traps were placed and several habitat parameters were measured at five land-use types ranging from natural forest to cacao agroforestry systems to open areas in 2009 and 2012. The effectiveness of dung beetles as bioindicators of environmental changes was evaluated by the IndValmethod, a method combining the specificity and fidelity of certain species with particular types of habitat or environmental conditions. Surprisingly, the results showed that the diversity of dung beetles in two types of cacao plantations were similar to the forest sites and were significantly higher than the open cultivated area. Of the 16 dung beetles species analyzed only four species could be suggested as indicator (characteristic) species while the majority of collected species were categorized as detector species. Two of them (Copris saundersi and Onthophagus forsteni) were associated with natural forest and cacao agroforestry system, thus were suggested as the indicator of shaded and cooler habitats whereas O. limbatus and $O$. tritubercan be suggested as indicator of unshaded and warmer habitats (bare land area).
\end{abstract}

Keywords: bioindicators, diversity, Scarabaeidae, habitat preferences, IndVal.

*Corresponding author : shahabuddin_slh@yahoo.com 


\section{INTRODUCTION}

The conversion of natural habitat to other land uses and its consequences on environmental changes has been acknowledged as the main driver of biodiversity loss at the Southeast Asia and global scales (Sodhi et al. 2004) and by 2100 the impact of land use changes on biodiversity is likely to be more significant than that of climate change, nitrogen deposition, species introductions and changing atmospheric concentrations (Sala et al. 2000; Young 2009). Therefore, detecting environmental changes due to land-use change is needed in order to avoid the continuous loss of biodiversity.

Bioindicators have been proven to be useful tools for monitoring and detecting changes in the environment. Species have different ecological requirements and their reactions to environmental variation are different from one another. Therefore, some species are better indicators than others (Dufrêne \& Legendre 1997). Some species are generalists occurring in a wide range of habitats (ubiquitous), while others are more specialized, requiring certain habitat characteristics (stenotopic).

A bioindicator can be defined as a species or a species group that reflects the abiotic or biotic state of the environment (environmental indicator), represents the impact of environmental change on a habitat, community or ecosystems (ecological indicator), or indicates the diversity of other species (biodiversity indicator) (McGeoch 1998). One of the reasons for using bioindicators is their cost-effectiveness. By using bioindicators it is possible to assess the impact of human activities on the biota, instead of examining the entire biota. Especially useful are species that provide early warning of change (Spellerberg 1993).

Environmental changes can cause different kinds of effects in the indicator, including physiological changes or changes in species number or abundance. The response of the species can be seen within the organism (e.g. heavy-metal concentrations), at the species level (species number and abundance) or at the community level (relations between species, e.g. pestpredator). Increase or decrease or abundance of species number might be directly caused by change in abiotic and/or biotic factors or indirectly by change of species assemblage of other species (Davis et al. 2001; Rainio \& Niemela 2003; Hambler et al. 2011; Gerlach et al. 2013).

A good bioindicator must fulfill several criteria. It has to be well-known taxonomically and ecologically, be distributed over a broad geographic area, have specialization to certain habitat requirements, provide early warning of change, be easy and cost-effective to survey, be relatively independent of sample size. Its response should reflect the response of other species, one should be able to differentiate between natural cycles or trends and those induced by anthropogenic stress, and it should be of potential economic importance (e.g. Noss 1990; Pearson \& Cassola 1992). However, it is difficult to find species or species groups which would have all of these criteria (Noss 1990; Pearson \& Cassola 1992). Requirements needed depend on the goal of the survey and the sensitivity to the anthropogenic disturbance is the most important criteria for monitoring environmental changes (Kremen et al. 1993). 
In this study dung beetles (Coleoptera: Scarabaeidae) was selected as a bioindicator group because it has been widely known as one of the best bioindicator groups (e.g. Halffter \& Favila 1993; McGeoch et al. 2002). Dung beetles have been proven to be very suitable to assess effects of disturbances on tropical ecosystems (Nichols et al. 2007; Shahabuddin 2010) and human habitat modification (Shahabuddin et al. 2010; Harvey et al. 2006) due to their abundance, highly varied with respect to species traits, and rapid responses to environmental change (Slade et al.2011; Shahabuddin et al. 2005 \& 2010; Spector 2006; Slade et al. 2011). Another advantage is their relatively complete species inventories and their data on the abundance of individual species can be achieved rapidly with standardized methods (Larsen \& Forsyth, 2005). Recently, dung beetles have been identified as one of the most cost-effective group for biodiversity survey in tropical forests (Kessler et al. 2011) and contributors in improving the level of soil carbon stocks (Kessler et al.2012).

One method used to quantify the 'bioindicator value' of a range of taxa is the indicator value (IndV al) method developed by Dufrene and Legendre (1997). This method combines measurements of the degree of specificity of a species to an ecological state, for example a habitat type, and its fidelity within that state (Dufrene \& Legendre 1997). Species with a high specificity and high fidelity within a habitat will have a high indicator value. High fidelity (frequency of occurrence) of a species across sample sites is generally associated with large abundance of individuals. Both characteristics facilitate sampling and monitoring, which are important requirements for a useful bioindicator (Kremen et al. 1994; McGeoch et al. 2002).

The indicator value method is important to conservation biology because it is conceptually straightforward and allows researchers to identify bioindicators for any combination of habitat types or areas of interest, e.g. existing conservation areas, or groups of sites based on the outcome of a classification procedure (McGeoch \& Chown 1998). Accordingly, IndValmethod has become the most robust and popular method used to measure indicator species analysis (Mc.Geoch et al. 2002; Aydin \& Kazak 2010; Negro et al. 2011).

In Central Sulawesi, forest habitats especially in the interior of Lore Lindu National Park (LLNP) are still relatively undisturbed while the margins of the park are characterized by a mosaic land-use type such as near-primary forests, secondary forests, forest gardens and plantations of cacao, maize and paddy rice fields (Gerold $e t$ al.2004). This study aimed to evaluate the effectiveness of dung beetles as bioindicator of environmental changes across land-use gradient in the margins of LLNP.

\section{MATERIALS AND METHODS}

\section{Study Area}

This study was carried out at the northern margin of the LLNP in Central Sulawesi, Indonesia. The Park, a local biodiversity hot spot covers an area of 229,000 ha and is located southeast of Palu, the capital of Central Sulawesi Province. All study sites were selected at the surrounding of the Palolo Valley in the vicinity of the villages of Bobo 
$\left(01^{\circ} 07^{\prime} 0.46^{\prime \prime} \mathrm{S}-119^{\circ} 59^{\prime} 702^{\prime \prime} \mathrm{E}\right)$ and were situated at an altitude between 790 and $985 \mathrm{~m}$ asl. Dung beetle communities were studied in five land-use types: natural forest (NF); secondary forest (SF); cacao agroforestry systems (cacao cultivated under natural shade tree at the forest margin (AC); Cacao plantation under monospecific shade tree dominated by Gliricidia sepium (CP); and open area (OA), cultivated either by Zea mays or Morus alba. Three replications sites for each land-use type were selected with distance at least $50 \mathrm{~m}$ from each other.

\section{Specimens Collection}

Dung beetles were sampled in $2500 \mathrm{~m}^{2}$ plots at 15 sites all using baited pitfall traps as described in Shahabuddin et al. (2010). Six traps were set up at the centre of each plot and placed with an interval of $10 \mathrm{~m}$. The traps were baited with ca. $30 \mathrm{~g}$ of fresh cattle (Bostaurus) dung and exposed six times from April to July in 2009 and March to June in 2012. Cattle dung has been widely used as bait for dung beetles, aside from human faeces (e.g. Erroizi et al. 2004; Andresen 2005; Mendoza et al. 2005). Our previous study also showed that at the same weight of bait (ca. $30 \mathrm{~g}$ ) cattle dung attracts the dung beetles with similar species composition found in the dung of anoa (Bubalus deppresicornis), an endemic herbivore of Sulawesi (Shahabuddin et al.2010).

The trapped specimens were removed after two days and preserved in Scheerpelz solution (Krell 2007). Later on, the samples were identified in the laboratory using available identification keys (e.g. Balthasar 1963) and by comparing to the reference collection of the Center for Biodiversity Research Tadulako University. Species which could not be identified, were sorted to morphospecies.

\section{Environmental Variables Measured}

Several habitat parameters (i.e. vegetation structure and microclimate) affecting the dung beetles diversity (see Davis et al. 2001; Shahabuddin 2010) were measured to characterize the land-use types including air temperature, relative humidity, canopy cover, and herb layer coverage. The relative humidity at the start and end of the exposure period were measured using a digital thermo-hygrometer (Corona ${ }^{\mathrm{R}}$ Model: GL 99) $1 \mathrm{~m}$ above ground while the canopy cover was visually estimated at four locations per site for a corridor of ca. $10 \mathrm{~m}$ inside the plot. The herb coverage was estimated at four plots of $2 \times 2 \mathrm{~m}^{2}$ randomly placed at ca. $5 \mathrm{~m}$ inside the plot. Based on the environmental variables measured all land-use types were then grouped using a two-dimensional scaling (Clarke 1993; StatSoft 2001).

\section{Data Analysis}

The three most widely used measures of species diversity were species richness, Shannon-Wiener Index and Simpson Index $\left(\mathrm{Si}=\sum \mathrm{pi}^{2}\right.$ ) (Lande 1996). Species richness of dung beetles was estimated using the second-order jackknife extrapolation method (Colwell, 2004), one of the best species richness predictor with respect to accuracy (e.g. Brose et al. 2003). As units for estimating the total species richness of land-use type, samples from all traps and replicates were pooled for individual sample 
times $(n=6)$ due to the close proximity between each trap and site. Effects of habitat type on diversity were tested using one-way ANOVA. Abundance data were transformed by $\log (\mathrm{n}+1)$ before analysis (Zar 1999). StatSoft 6.0 software (2001) was used to perform all statistical analyses. All diversities measured were computed with EstimateS Version 7.00 program (Colwell 2004) by randomizing the ranking of samples 50 times. Only species sampled in both sample periods (2009 and 2012) were analyzed.

The effectiveness of each dung beetles species as bioindicators were identified for each habitat type using the indicator value (IndVal) method (Dufrene \& Legendre 1997).This method combines measures of specificity and fidelity and provides an indicator value for each species, as a percentage (Dufrene \& Legendre 1997). Specificity measure: $A_{i j}=$ Nindividuals $_{i j} /$ Nindividuals $_{i}$ where Nindividuals in $_{i j}$ the mean number of species $i$ across sites of group $j$, and Nindividuals $s_{i}$ is the sum of the mean numbers of individuals of species $i$ over all groups. Fidelity measure: $B i j=N$ sites $_{i j} / N_{\text {sites }}$ where $N$ sites $_{i j}$ is the number of sites in cluster (habitat) $j$ where species $i$ is present, and $N$ sites $j_{j}$ is the total number of sites in that cluster. The percentage indicator value for species $i$ in cluster (habitat) $j$ is then: IndV $a l_{i j}=A_{i j} \times B_{i j} \times 100$. The indicator values are the highest (100) when all individuals of a species are found in a single habitat (high specificity) and when the species occurs in all samples of that habitat (high fidelity). Species with IndVal between $50 \%$ to less than $70 \%$ is categorized as the detector or generalist species while those species with significant IndV al of greater than $70 \%$ were regarded as characteristic indicator species for the particular habitat type (Mc.Geoch et al. 2002).

\section{RESULTS AND DISCUSSIONS}

\section{Diversity of Dung Beetles}

A total of 1996 dung beetles specimens were collected during the study period. They belongs to four genera (dominated by Onthophagus) and 28 species (for complete species list see Shahabuddin 2013). However, only 16 species were recorded in both sample periods (2009 and 2012). The diversity of dung beetles changed from natural forest, to agroforestry cacao and to open area. Interestingly, the diversity of dung beetles in both forest types and the two types of cacao plantations tend to be similar but significantly higher than that in open cultivated area (Table 1). Hence, this study showed that secondary forest and agroforestry system may support a high portion of tropical dung beetles species than in the bare land and thereby in line with the findings by Nichols et al. (2007) and our previous study (Shahabuddin et al. 2010).

The fact that agroforestry system has high potency for conserving high biodiversity supported by previous study (e.g. McNely \& Scroth 2006; Schulze et al. 2010). However, the results may also be related with the spatial distribution of our study sites. The agroforestry cacao sites were closer to the natural and secondary forest than to the open area and has a high opportunity to be colonized by dung beetles coming from the forest sites. Therefore, the high diversity of dung beetles at the cacao agroforestry system is also related to their close proximity to the forest sites. It has 
Table 1. Diversity of dung beetles at five habitat type. $\mathrm{NF}=$ Natural Forest; $\mathrm{SF}=$ Secondary Forest; $\mathrm{AC}=$ Cacao agroforestry system $; \mathrm{CP}=$ Cacao plantation; $\mathrm{OA}=$ open area

\begin{tabular}{ccccc}
\hline $\begin{array}{c}\text { Land-use } \\
\text { type }\end{array}$ & $\begin{array}{c}\text { Estimated species richness } \\
\text { (Jack-2) } \\
\left(\mathrm{F}_{4,10}=6.27, P<0.05\right)\end{array}$ & $\begin{array}{c}\text { Number of species recorded } \\
F 4,10=3 \cdot 60, P<0 \cdot 005\end{array}$ & H' & Simpsom \\
\hline $\mathrm{NF}$ & $14.3 \mathrm{a}$ & $9 \mathrm{ab}$ & 1.6 & 4.2 \\
$\mathrm{SF}$ & $14.4 \mathrm{a}$ & $10.7 \mathrm{ab}$ & 1.7 & 4.2 \\
$\mathrm{AC}$ & $15 \mathrm{a}$ & $11 \mathrm{a}$ & 1.7 & 4.3 \\
$\mathrm{CP}$ & $13.6 \mathrm{a}$ & $10 \mathrm{ab}$ & 1.7 & 4.5 \\
$\mathrm{OA}$ & $8.7 \mathrm{~b}$ & $6.3 \mathrm{~b}$ & 1.3 & 3.1 \\
\hline
\end{tabular}

been reported that neighboring forest or isolation from forest may determine insect communities in tropical land-use systems (Tscharntke et al. 2005; Klein et al. 2006). Agroforestry systems can be part of the habitat for many forest species using it for foraging, but they may also harbour largely independent populations.

Nonetheless, this study suggests that the preservation of environmental heterogeneity should be encouraged for conserving dung beetles in the LLNP, Central Sulawesi. This is important because high diversity of dung beetles in tropical land-use will enhance its ecosystem function and this ecological services will be diminished by increasing human dominated land-use (Shahabuddin 2011; Slade et al. 2011; Kudavidanage et al. 2012). In more natural and heterogeneous habitats, such as natural forest and agroforestry system, dung removal, biological control and seed dispersal activities of dung beetles were higher than in homogenous or disturbed habitats (Slade et al. 2007; Nichols et al. 2008; Shahabuddin 2011; Slade et al.2011).

\section{Indicator Species}

Because the dung beetles diversity at the forest sites (natural forest and secondary forest) and the cacao plantation sites (agroforestry cacao and cacao plantation) were similar to each other but significantly higher than in the open area (Table 1), the indicator species analysis land-use type is only classified into three groups, i.e: forest, agroforestry cacao and open area. The high similarity of environmental parameter measured among these three groups of land-use types was supported by ANOVA showing that temperature and herb coverage decreased from the natural and secondary forest to the open area while canopy and humidity showed a reverse pattern. However, a highly significant difference of environmental parameter measured was only recorded in the open area (Fig. 1). This land-use type grouping was also supported by the ordination technique using multidimensional scaling (Fig. 2).

Based on IndV al analysis of 16 dung beetles species collected in two sampling years (2009 and 2012), this study recorded four species having IndVal less than $70 \%$ and therefore, can be used as indicator (characteristic) species that are: Copris saundersi at forest sites, Onthophagus forsteni at cacao plantation, as well as O. trituber and O. limbatus at open area (Table 2). Copris saundersi and Onthophagus forsteni are suggested to be used as indicators of cooler and shaded habitats such as forest sites and cacao agroforestry 

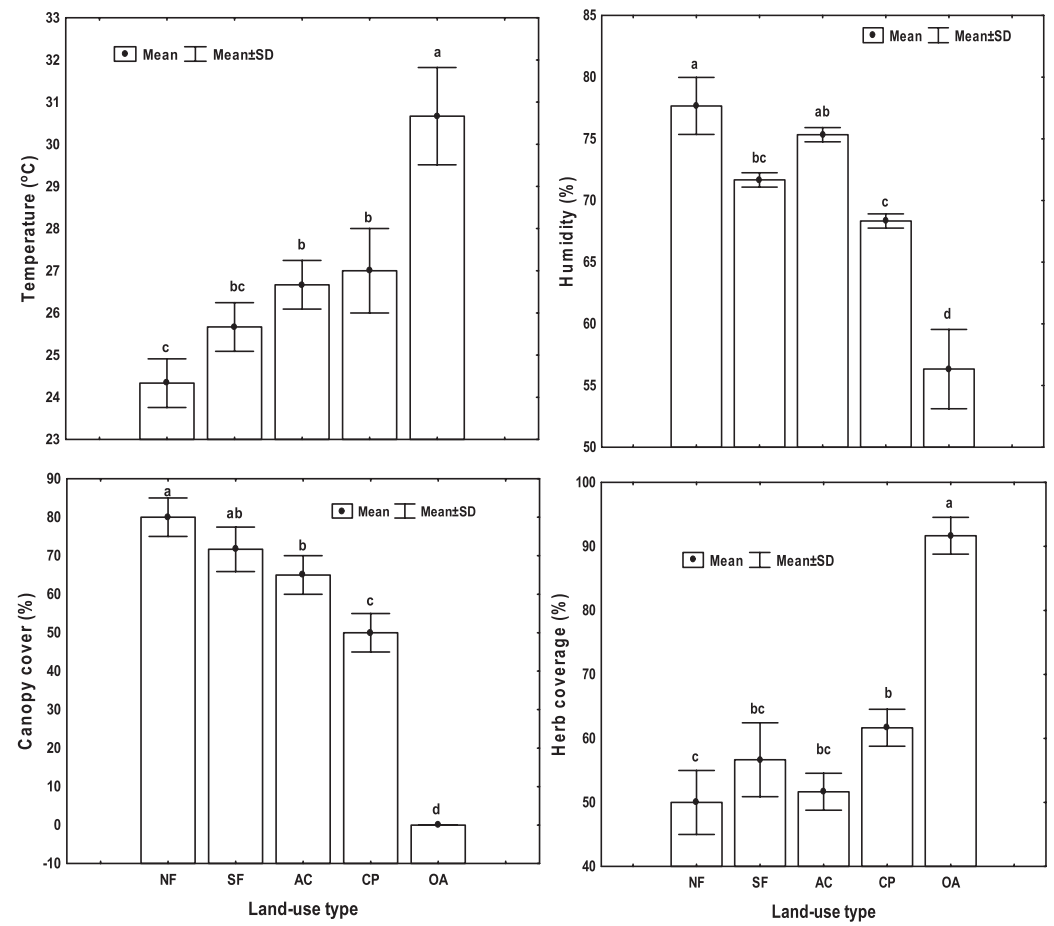

Figure 1. The effects of land use change on a) Temperature (ANOVA: $F(4,10)=25.15, \mathrm{p}<0.01$ ), b) Relative humidity (ANOVA:F $(4,10)=62.88, \mathrm{p}<0.01$ ), c) Canopy cover (ANOVA: $\mathrm{F}(4,10)=139.81, \mathrm{p}<0.01$ ), and $\mathrm{d}$ ) Herb layer coverage (ANOVA: $\mathrm{F}(4$, 14) $=52.15, \mathrm{p}<0.01)$. All variables were averaged per land-use type. $\mathrm{NF}=$ Natural Forest; $\mathrm{SF}=$ Secondary Forest $\mathrm{AC}=$ Agroforestry cacao; $\mathrm{CP}=$ Cacao plantation; $\mathrm{OA}=$ open area. Significant differences between habitat types were indicated by different letters over the standard error (based on Tukey's HSD post-hoc test)

system, while $O$. trituber and $O$. limbatus most likely indicate warmer and unshaded habitats (e.g. open cultivated area). These characteristic species (IndV $a l$ of $>70 \%$ ) are unlikely to move from their requisite to other habitat types, even under changing conditions within this habitat. Accordingly, populations of these species need only to be monitored within the specific habitat.

Beside indicator species, this study has recorded several generalist or moderate species with IndV $\mathrm{Val}$ between $50 \%$ to less than $70 \%$. These species were therefore, not characteristic species, as they do not have high IndVal of more than $70 \%$ for any particular habitat. Species meeting these criteria are unlikely to respond very rapidly to changing habitat conditions. They can invade either close canopy or moist habitat e.g. natural forest, cacao agroforestry or cacao plantation but also open or warmer environment such us open area. Furthermore, these species are less likely to become more vulnerable than indicator species, because a variety of habitats or ecological states, rather than only a single one, provide suitable resources for them and accordingly this group of species will be useful for longer-term monitoring. 


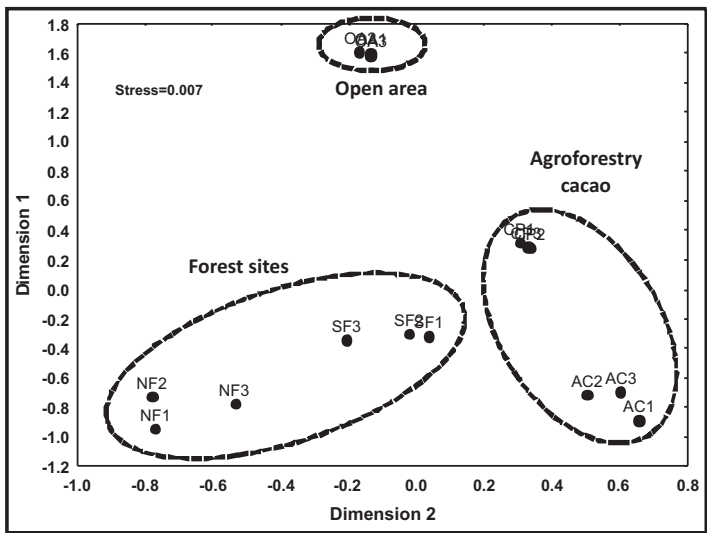

Figure 2. Multidimensional scaling (MDS) placing the five land-use type studied in three groups based on several habitat parameters measured. $\mathrm{NF}=$ Natural Forest; $\mathrm{SF}=$ Secondary Forest; $\mathrm{AC}=$ Agroforestry cacao; $\mathrm{OA}=$ open area

Table 2. Indicator values (IndVal percentage) for dung beetle species recorded in three group of habitats. Species with IndVal $>70 \%$ is categorized as a characteristic species (C) while species with IndVal $50 \leq 70 \%$ is a detector species (D) of certain habitat type

\begin{tabular}{lccccccc}
\hline \multirow{2}{*}{ Species* } & \multicolumn{3}{c}{$\begin{array}{c}\text { Forest } \\
\text { Sites }\end{array}$} & \multicolumn{2}{c}{$\begin{array}{c}\text { Agroforestry } \\
\text { cacao }\end{array}$} & Open area & $\begin{array}{c}\text { Species } \\
\text { category }\end{array}$ \\
\cline { 2 - 9 } & 2009 & 2012 & 2009 & 2012 & 2009 & 2012 & \\
\hline Copris macacus & 67.4 & 13.3 & 22.6 & 20.0 & 0.0 & 0.0 & - \\
Copris punctulatus & 12.1 & 22.2 & 30.3 & 44.4 & 24.2 & 0.0 & - \\
Copris saundersi & $\mathbf{9 5 . 8}$ & $\mathbf{9 1 . 7}$ & 0.0 & 0.0 & 0.0 & 0.0 & $\mathrm{C}$ \\
Onthophagus cf.wallacei & 22.4 & 41.5 & 10.5 & 41.5 & 67.0 & 1.5 & - \\
Onthophagus forsteni & 0.0 & 3.7 & 33.3 & $\mathbf{7 4 . 1}$ & 0.0 & 0.0 & $\mathrm{C}$ \\
Onthophagus fulvus & 0.0 & 16.7 & 53.6 & 61.8 & 7.1 & 21.5 & $\mathrm{D}$ \\
Onthophagus rectecornutus & 0.0 & 0.0 & 0.0 & 33.3 & 66.7 & 0.0 & - \\
Onthophagus ribbei & 60.5 & 32.4 & 8.4 & 37.1 & 0.4 & 1.0 & $\mathrm{D}$ \\
Onthophagus rudis & 5.3 & 39.5 & 29.3 & 51.2 & 13.3 & 9.3 & $\mathrm{D}$ \\
Onthophagus scrutator & 1.3 & 37.5 & 67.8 & 57.1 & 5.8 & 0.0 & $\mathrm{D}$ \\
Onthophagus sp.1 & 63.6 & 62.8 & 19.4 & 30.2 & 6.9 & 4.7 & $\mathrm{D}$ \\
Onthophagus sp.2 & 33.3 & 0.0 & 0.0 & 33.3 & 0.0 & 0.0 & - \\
Onthophagus sp.3 & 0.0 & 46.9 & 66.7 & 38.6 & 0.0 & 14.5 & $\mathrm{D}$ \\
Onthophagus trituber & 0.0 & 4.2 & 7.1 & 4.2 & $\mathbf{9 2 . 9}$ & $\mathbf{7 5 . 0}$ & $\mathrm{C}$ \\
Phaechrous emarginatus & 58.3 & 35.7 & 0.0 & 41.9 & 0.0 & 22.4 & - \\
Onthophagus limbatus & 0.7 & 0.3 & 0.2 & 19.6 & $\mathbf{9 7 . 3}$ & $\mathbf{7 7 . 3}$ & $\mathbf{C}$ \\
\hline
\end{tabular}

* Only species recorded in both sample years (2009 and 2012) were included in the IndVal analyses 


\section{CONCLUSIONS}

The fact that diversity of dung beetles at secondary forest and agroforestry system has no significant differences with natural forest has important implications on landscape management aiming at maintaining a high biodiversity. Besides natural forest sites, certain agroecosystems like cacao agroforestry also have potency to maintain a high local diversity. Dung beetles have high potency to be used as bioindicator (i.e. ecological indicator) in relation with their fidelity and specificity to a particular type of habitat. Copris saundersi and Onthophagus forsteni can be suggested as indicator (characteristic) species of cooler and shaded habitats (e.g. forest sites and cacao agroforestry system), while $O$. trituber and $O$. limbatus can be suggested as indicator of warmer and unshaded habitats (e.g. open cultivated area). The remaining dung beetles species found across the land-use types in the margin of LLNP, Central Sulawesi are better to be categorized as detector or moderate species.

\section{ACKNOWLEDGEMENTS}

The authors gratefully acknowledge the Directorate of Higher Education Ministry of Education and Culture Indonesia for providing the National Strategies Research Grant (Contract No. 027/SP2H/Dit.Litabmas/III/2012), and to the Head of Lore Lindu National Park for his permission to conduct this study.

\section{REFERENCES}

Andresen E. 2005. Effects of Season and Vegetation Type on Community Organization of Dung Beetles in a Tropical Dry Forest. Biotropica 37(2): 291-300.

Aydin G, Kazak C. 2010. Selecting indicator species habitat description and sustainable land utilization: a case study in amediterranean delta.International Journal of Agriculture \& Biology 12: 931-934.

Balthasar V.1963. Monographie der Scarabaeidae und Aphodiidae der palaearktischen und orientalischen Region.Band 1.Verlag der Tschechoslawakischen Akademie der Wissenschaften. Prague.

Brose U, Martinez ND, Williams RJ. 2003. Estimating species richness:sensitivity to sample coverage and insensitivity to spatial patterns. Ecology 84 (9): 2364-2377.

Clarke KR. 1993. Non-parametric multivariate analyses of changes in community structure. Australian Journal Ecology 18: 117-143.

Colwell RK. 2004. EstimateS: Statistical estimation of species richnes and shared species from samples. Version 7.User's Guide and application.http://purl.oclc.org/estimates.

Davis AJ, Holloway JD, Huijbregts H, Krikken J, Kirk-Spriggs AH, Sutton SL. 2001. Dung beetles as indicators of change in the forests of northern Borneo. Journal of Applied Ecology 38: 593-616.

Dufrêne M, Legendre P. 1997. Species assemblages and indicator species: the need for a flexible asymmetrical approach. Ecological Monographs 67:345-366.

Errouissi F, Haloti S, Robert PJ, Idrissi AJ, Lumaret JP. 2004. Effect of the attractiveness for dung beetles of dung pat origin and size along climatic gradient. Environ. Entomol. 33(1): 45-53.

Gerold G, Fremery M,Guhardja, E. 2004. Land-use, nature conservation and the stability of rainforest margins in Southeast Asia.Springer, Berlin. 534 pp. 
Gerlach J, Samways M, Pryke J. 2013. Terrestrial invertebrates as bioindicators: an overview of available taxonomic groups. Journal of Insect Conservation,17, 831-850.

Halffter G, Favila ME. 1993. The Scarabaeinae (Coleoptera): an animal group for analysing, inventorying and monitoring biodiversity in tropical rainforest and modified landscapes. Biology International 27:15-21

Hambler C, Henderson PA, Speight MR. 2011. Extinction rates, extinction-prone habitats, and indicator groups in Britain and at larger scales. Biological Conservation,144, 713-721.

Harvey CA, Gonzalez J, Somarriba E. 2006. Dung beetle and terrestrial mammal diversity in forests, indigenous agroforestry systems and plantain monocultures in Talamanca, Costa Rica. Biodiversity and Conservatio 15: 555-585.

Kessler M, Abrahamczyk S, Bos M, Buchori D,Putra DD, Gradstein SR, Höhn P, Kluge J, Orend F, Pitopang R, Shahabuddin S, Schulze CH, Sporn SG, Steffan-DewenterI,Tjitrosoedirdjo SS, Tscharntke T. 2011 Cost-effectiveness of plant and animal biodiversity indicators in tropical forest and agroforest habitats. Journal of Applied Ecology 48: 330-339.

Kessler M, Herte D, Jungkunst HF, Kluge J, Abrahamczyk S, Bos M, Buchori D, Gerold G, Gradstein SR, Ko " hler S, Leuschner C, Moser G, Pitopang R, Shahabuddin S, Schulze CH, Sporn SG, Steffan-Dewenter I, Tjitrosoedirdjo SS, Tscharntke T.2012. Can joint carbon and biodiversity management in tropical agroforestry landscapes be optimized? PLoSONE7(10): e47192. doi:10.1371/journal.pone.0047192.

Klein AM, Steffan-Dewenter I, Buchori D, Tscharntke T. 2006. Rain forest promotes trophic interactions and diversity of trap-nesting Hymenoptera in adjacent agroforestry. Journal of Animal Ecology 75: 315323.

Kudavidanage EP, Qie L, Lie JSH. 2012. Linking biodiversity and ecosystem functioning of dungBeetles in south and southeast asian tropical rainforests. The Raffles Bulletin Of Zoology. Supplement No. 25: 141-154

Krell FT. 2007. Dung Beetle Sampling Protocols. DenverMuseum of Nature \& Science (DMNS) Technical Report200-6:1-11.http://www.dmns.org/media/5782/130-DMNSTechRep2007-6.pdf.

Kremen C, Merenlander AM, Murphy DD. 1994. Ecological monitoring: a vital need forintegrated conservation and development programs in the tropics. Conservation Biology 8: 388-397.

Lande R. 1996. Statistics and partitioning of species diversity, and similarity among multiple communities.Oikos 76:5-13.

Larsen TH, Forsyth A. 2005. Trap spacing and transect design for dung beetle biodiversity studies. Biotropica $37(2): 322-325$.

McGeoch MA. 1998. The selection, testing and application of terrestrial insects as bioindicators. Biological Review 73:181-201.

McGeoch MA, Van Rensburg BJ, Botes A. 2002. The verification and application of bioindicators: a case study of dung beetles in a savanna ecosystem. Journal of Applied Ecology39: 661-672.

McGeoch MA, Chown SL. 1998. Scaling up the value obioindicators. Trends in Ecology and Evolution13: 46-47.

Mcneely, JA and G, Schroth. 2006. Agroforestry and biodiversity conservation - traditional practices, present dynamics, and lessons for the future. Biodiversity and Conservation 15:549-554.

Mendoza CAO, Rios AM, Cano EB, Corte's JLN. 2005. Dung beetle community (Coleoptera: Scarabaeidae: Scarabaeinae) in a tropical landscape at the Lachua Region, Guatemala. Biodiversity and Conservation 14: 801-82.

Negro M, Palestrini C, Giraudo MT, Rolando A. 2011. The effect of local environmental heterogeneity on species diversity of alpine Dung beetles (Coleoptera: Scarabaeidae). Eur. J. Entomol. 108: 91-98.

Nichols E, Larsen T, Spector S, Davis AL, Escobar F, Favila M, Vulinec K. 2007. Global dung beetle response to tropical forest modification and fragmentation: a quantitative literature review and meta-analysis. Biological Conservation 137:1-19.

Nichols E, Spector S, Louzada J, Larsen T, Amesquita S, Favila ME. 2008. Ecological functions and ecosystem services provided by Scarabaeinae dung beetles. Biological Conservation 141 (6): 1461-1474.

Noss RF. 1990. Indicators for monitoring biodiversity: a hierarchical approach. Conservation Biology4: 355-364. 
BIOTROPIA Vol. 21 No. 1, 2014

Pearson DL, Cassola F. 1992. World-wide species richness patterns of tiger beetles (Coleoptera:Cicindelidae): indicator taxon for biodiversity and conservation studies. Conservation Biology 6:376-391.

Rainio J, Niemelä J. 2003. Ground beetles (Coleoptera: Carabidae) as bioindicators.Biodiversityand Conservation12: 487-506.

Sala OE, Chapin FS, Armesto JJ, Berlow E, Bloomfield J, Dirzo R, Huber-Sanwald E, Huenneke LF, Jackson RB, Kinzig A, Leemans R, Lodge DM, Mooney HA, Oesterheld M, Poff NL, Sykes MT, Walker BH,Walker M,Wall DH. 2000. Review: Global Biodiversity Scenarios for the Year 2100. Science 287: 1770-1774.

Schulze CH, Schneeweihs S, Fiedler K. The potential of land-use systems for maintaining tropical forest butterfly diversity. In Tropical Rainforests and Agroforests Under Global Change 73-96. Edited by Tschartnke $e t$ al. New York: Springer 2010:73-96.

Shahabuddin, Schulze CH,Tscharntke T. 2005. Changes of dung beetle communities from rainforests towards agroforestry systems and annual cultures. Biodiversity and Conservation 14: 863-877.

Shahabuddin. 2010. Diversity and community structure of dung beetles (Coleoptera: Scarabaeidae) across a habitat disturbance gradient in Lore Lindu National Park, Central Sulawesi. Biodiversitas 11 (1):29-33.

Shahabuddin, Hidayat P, Noerdjito WA, Manuwoto S, Schulze CH. 2010. Diversity and body size of dung beetles attracted to different dung types along a tropical land-use gradient in Sulawesi, Indonesia. Journal of Tropical Ecology 26 (1) : 53-65.

Shahabuddin. 2011. Effect of land use change on ecosystem function of dung beetles: experimental evidence from Wallacea Region in Sulawesi, Indonesia.JurnalBiodiversitas 12 (3): 177-181

Shahabuddin. 2013. Contribution of alpha and beta diversity across land-use type to the regional diversity of dung beetles in Central Sulawesi. HAYATI Journal of Biosciences 20 (2):72-79.

Slade EM, Mann DJ, Villanueva JF, Lewis OT. 2007. Experimental evidence for the effects of dung beetle functional group richness and composition on ecosystem function in a tropical forest. Journal of Animal Ecology76: 1094-1104.

Slade EM, Mann DJ, Lewis OT. 2011. Biodiversity and ecosystem function of tropical forest dung beetles under contrasting logging regimes. Biological Conservation 144: 166-174.

Sodhi NS, Koh LP, Brook BW, Peter KLNg. 2004. Southeast Asian biodiversity: the impending disaster. Trends in Ecology and Evolution. 19 (12): 654-660.

Spector S. 2006. Scarabaeine Dung Beetles (Coleoptera: Scarabaeidae: Scarabaeinae): An Invertebrate Focal Taxon for Biodiversity Research and Conservation. The Coleopterists Bulletin 5: 71-78.

Spellerberg IF. 1993. Monitoring Ecological Change. Cambridge University Press, Cambridge, UK.

StatSoft Inc. 2001. STATISTICA (data analysis software system), version 6.www.statsoft.com.

Tscharntke T, Klein AM, Kruess A, Steffan-Dewenter I, Thies C. 2005. Landscape perspectives on agricultural intensification and biodiversity-ecosystem service management. Ecology Letter 8: 857-874.

Young RH. 2009. Land use and biodiversity relationships. Journal of Land Use Policy 26S: S178-S186.

ZarJH. 1999. Biostatistical Analysis. 4th edition. Prentice-Hall Inc. New Jersey.USA. 